\title{
Cholesterol oxidase interference on the emergence and viability of cotton boll weevil larvae ${ }^{(1)}$
}

\author{
Roseane Cavalcanti Santos(2), Rose Gomes Monnerat ${ }^{(3)}$, Maria de Fátima Grossi de Sá(3), \\ Célia Maria Torres Cordeiro ${ }^{(3)}$, Ana Cristina Gomes ${ }^{(3)}$ and Eugen Silvano Gander ${ }^{(3)}$
}

\begin{abstract}
The aim of this work was to evaluate the influence of the enzyme cholesterol oxidase (Coase) on emergence and viability of larvae of the cotton boll weevil (Anthonomus grandis Boheman, 1843). A series of bioassays was performed with eggs and neonate larvae exposed to different enzyme concentrations in artificial diet. Larval survival was affected at all enzyme concentrations tested, and the six-day $\mathrm{LD}_{50}$ was $53 \mu \mathrm{g} / \mathrm{mL}\left(\mathrm{CI}_{95 \%}\right.$ : 43-59). Coase also interfered with hatching of larvae after eggs were floated for $15 \mathrm{~min}$ in Coase solution at different concentrations. Observations at the light and electronic microscopic level of midguts from larvae fed on artificial diet containing $53 \mu \mathrm{g} / \mathrm{mL}$ of Coase and collected at six days revealed highly vacuolated regions in the epithelial cells as well as partial degradation of the basal membrane and microvilli.
\end{abstract}

Index terms: Anthonomus grandis, Insecta, animal tissues, epithelium, intestinal histology.

\section{Interferência da colesterol oxidase na eclosão e viabilidade das larvas do bicudo-do-algodoeiro}

\begin{abstract}
Resumo - O objetivo desse trabalho foi avaliar a influência da colesterol oxidase (Coase) na eclosão e viabilidade de larvas do bicudo-do-algodoeiro (Anthonomus grandis Boheman, 1843). Uma série de bioensaios foram conduzidos com ovos e larvas neonatas, os quais foram expostos a diferentes concentrações da enzima em dieta artificial. A sobrevivência das larvas foi afetada em todas as concentrações testadas, e a $\mathrm{DL}_{50}$, no sexto dia, foi de $53 \mu \mathrm{g} / \mathrm{mL}$ (IC ${ }_{95 \%}$ : 43-59). A Coase também interferiu na eclosão das larvas quando os ovos foram submersos por 15 min em solução de Coase, em diferentes concentrações. Observações feitas ao microscópio de luz e eletrônico no intestino médio das larvas alimentadas durante seis dias com dieta artificial contendo $53 \mu \mathrm{g} / \mathrm{mL}$ de Coase revelou regiões altamente vacuolizadas nas células epiteliais, bem como degradação parcial das membranas basal e microvilli.
\end{abstract}

Termos para indexação: Anthonomus grandis, Insecta, tecido animal, epitélio, histologia intestinal.

\section{Introduction}

Since its introduction to Brazil, 19 years ago, the boll weevil (Anthonomus grandis Boheman, 1843) has become the most damaging pest of cotton (Gossypium hirsutum L.) crop. Before its introduc-

\footnotetext{
(1) Accepted for publication on May 20, 2002.

${ }^{(2)}$ Embrapa-Centro Nacional de Pesquisa de Algodão, Caixa Postal 174, CEP 58107-720 Campina Grande, PB, Brazil E-mail: roseane@cnpa.embrapa.br

${ }^{(3)}$ Embrapa-Centro Nacional de Pesquisa de Recursos Genéticos e Biotecnologia, Caixa Postal 02372, CEP 70770-900 Brasília, DF, Brazil. E-mail: rose@ cenargen.embrapa.br, fátima@cenargen.embrapa.br, celia@cenargen.embrapa.br anagomes@cenargen.embrapa.br, egander@cenargen.embrapa.br
}

tion, Brazil was the world's largest exporter of cotton fibers; nowadays, the production has been dramatically reduced and is insufficient, even, to satisfy the annual national demand of 850,000 ton (Beltrão, 1999). Research has produced several technologies aiming to minimize the damage caused by this pest, e.g. earliness and short cycle cultivars. The principal control, however, is obtained through the application of chemical insecticides. The drawbacks of this approach are high costs of the insecticides and the relatively narrow window during the crop's development when insecticide application is effective. This is due to the fact that boll weevil eggs are deposited within the cotton squares and bolls and the larvae develop entirely within those structures. If insecti- 
cide application is not made at the right time, the reduction in yield can amount to over $70 \%$ (Gabriel et al., 1986). Besides, the indiscriminate and incorrect use of insecticides has lead to extremely negative consequences, affecting humans directly and/or indirectly via the agricultural ecosystems (Almeida, 2000).

Several research centers have made efforts to search and evaluate new insecticidal proteins suitable for boll weevil control in particular lectin and amylase and proteinase inhibitors; however, according to Greenplate et al. (1995), these molecules retard growth and increase the time of development of the parasite, but seem to afford little acute toxicity.

As an alternative, Purcell et al. (1993, 1994) tested several microbial filtrates for insecticidal activity against boll weevil and found that two Streptomyces culture filtrates killed boll weevil larvae in feeding studies. It was found that the active component was cholesterol oxidase. In neonate and $2^{\text {nd }}$ instar larvae fed on diets containing this enzyme, the epithelial cell layer of the midgut was disrupted at low doses and complete lysed at high ones. Greenplate et al. (1995) showed the effect of cholesterol oxidase on fertility and egg viability using artificial bolls treated with a $50 \mu \mathrm{g} / \mathrm{mL}$ of enzyme solution, and concluded that cholesterol oxidase might represent an alternative to the insecticides currently used for boll weevil control.

The objective of this work was to evaluate the influence of cholesterol oxidase on emergence and viability of larvae of the cotton boll weevil.

\section{Material and Methods}

The enzyme Streptomyces cholesterol oxidase (EC 1.1.3.6) (SIGMA C.8649) was used throughout the experiments. Artificial diet was prepared with soybean meal enriched with vitamins and mineral salts in a medium optimized by Monnerat et al. (1999). Cholesterol oxidase was incorporated into the diet at the concentrations $41,47,63,59,65,71$ and $77 \mu \mathrm{g} / \mathrm{mL}$. Bioassays were carried out at constant environmental conditions in a bio-climatic cabinet programmed for a 14:10 day/night rhythm, $28^{\circ} \mathrm{C}$ and $65 \%$ relative humidity.

In order to test the influence of the enzyme on emergence, ten batches of 25 viable eggs were immersed in $18 \% \mathrm{CuSO}_{4}$ solution for one min, washed in distilled water and disinfected in $0.3 \%$ benzalkonium chloride for one hour. Subsequently the eggs were floated in $500 \mu \mathrm{L}$ of solutions containing $41,47,53,59,65,71$ and $77 \mu \mathrm{g} / \mathrm{mL}$ enzyme for $15 \mathrm{~min}$, distributed on a $12 \mathrm{~cm}$ diameter Petri dish containing artificial diet and incubated in a bio-climatic cabinet. Evaluation was done on the $4^{\text {th }}$ day.

The effect of cholesterol oxidase on larval survival was tested as follows: ten batches of sixty neonate larvae each were fed on artificial diet containing $1 \mathrm{~mL}$ Coase at 41 , $47,53,59,63,71$ and $77 \mu \mathrm{g} / \mathrm{mL}$. Plates containing the larvae were placed in a bio-climatic cabinet, and evaluation was made seven days after initiation of the experiment.

For the histological tests, midguts from larvae fed for six days on artificial diet containing cholesterol oxidase (Coase) at $53 \mu \mathrm{g} / \mathrm{mL}$ were dissected in $0.1 \mathrm{M}$ cacodylate buffer ( $\mathrm{pH}$ 7.3). The tissue was fixed in $0.1 \mathrm{mM}$ sodium cacodylate buffer ( $\mathrm{pH} 7.3$ ) containing $2 \%$ glutaraldehyde, $4 \%$ paraformaldehyde and $5 \mathrm{mM}$ calcium chloride and postfixed in a solution containing $2 \%$ osmium tetroxide and $1.6 \%$ potassium ferricyanide. Then, samples were dehydrated in an acetone gradient and embedded in Spurr. Semi-thin $500 \mathrm{~nm}$ sections, obtained with the Leica Ultracut were stained with toluidine blue for observations in the light microscope. Ultrathin $60 \mathrm{~nm}$ sections were stained with uranyl acetate for observation in the electron microscope.

The data bearing on the interrelationship between dose and larval mortality were analyzed by Probit regression, using the SAS program (SAS Institute, 1999) to estimate the $\mathrm{LD}_{50}$ and its $95 \%$ confidence interval (CI $95 \%$ ). The control mortality rate was included in the model. The $\chi^{2}$ value was used to measure the fit of the Probit regression line with the observed points.

\section{Results and Discussion}

The linear effect of different doses of cholesterol oxidase on the emergence of boll weevil larvae is shown in Table 1. A clear-cut dose-dependency with respect to hatching rate is evident $(\mathrm{P}<0.001)$. This result suggests that Coase molecules are able to penetrate the egg shell affecting the larval development. The evaluation of this assay was done after four days; by then unhatched eggs assumed a withered and opaque aspect and emerged larvae showed retarded development and low mobility (Figure 1). 
According to Lange (1992), treatment with Coase can promote the passive permeability of plasma membranes to small solutes such as $\mathrm{K}^{+}$ions which, in turn, could lower egg turgor causing the withered aspect as well as cellular lysis and oxidation of intracellular components resulting in the reduced emergence rate.

As to the larval assay, the Probit model revealed that larval mortality is dependent on the enzyme concentration. The goodness of fit in this model produced a Pearson $\chi^{2}=3.5$ with five degrees of freedom and $\mathrm{P}=0.62$. In this case, confidence interval (CI) for $\mathrm{LD}_{50}$ does not request adjustment by a het-

Table 1. Influence of cholesterol oxidase (Coase) concentration on the emergence and mortality rates of boll weevil larvae ${ }^{(1)}$.

\begin{tabular}{ccc}
\hline Coase dose $(\mu \mathrm{g})$ & Emergence rate $^{(2)}$ & Mortality rate $^{(3)}$ \\
\hline 41 & $62(43-88)$ & $31(31-58)$ \\
47 & $58(41-83)$ & $37(37-62)$ \\
53 & $53(37-76)$ & $49(49-69)$ \\
59 & $51(36-73)$ & $54(53-72)$ \\
65 & $49(34-70)$ & $55(55-73)$ \\
71 & $42(29-60)$ & $67(66-80)$ \\
77 & $32(22-46)$ & $72(71-83)$ \\
\hline CV $(\%)$ & 14 & 12 \\
\hline
\end{tabular}

${ }^{(1)} \mathrm{CI}$ 95\% (Dunnett's two-tailed t-test) of log-transformed variable are enclosed in parenthesis; all comparisons were significant at the 0.05 level; $\mathrm{CI}$ : confidence interval. ${ }^{(2)}$ Emergence $=[100 \mathrm{x}$ (number of emerged larvae after treatment/number of emerged larvae in the control $(15 \pm 2.0)$ ]; data refer to the mean values from 10 assays of 25 eggs/assays and to back-transformed comparisons dose vs. control. (3) Mortality data were obtained from 600 neonate larvae; natural mortality was estimated at $34 \pm 4.4 \%$.

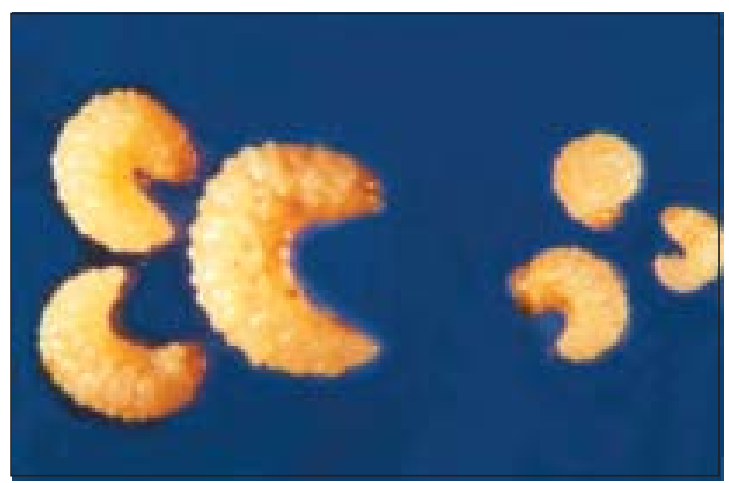

Figure 1. Cotton boll weevil larvae (second and third instar) reared on cholesterol oxidase-containing diet (at right) and without treatment (control, at left). Magnification: $\mathrm{x} 49$. erogeneity factor. $\mathrm{LD}_{50}$ is $53 \mu \mathrm{g} / \mathrm{mL}\left(\mathrm{CI}_{95 \%}\right.$ : 43-59). These results do not include any effect due to natural mortality rate, estimated at $34 \pm 4.4 \%$.

Light and transmission microscopic observations of midguts from control larvae showed a well-developed striated border in the apical part of the cells, a conserved basal membrane as well as few cytoplasmatic vacuoles (Figures 2A, 3A, 3B and $3 C)$. In addition, it appears that the mitotic activity in control intestines is more intense than in enzymetreated material (Figure 2A). In contrast, midguts from larvae fed on artificial diet containing Coase revealed partial degradation of the microvilli and the

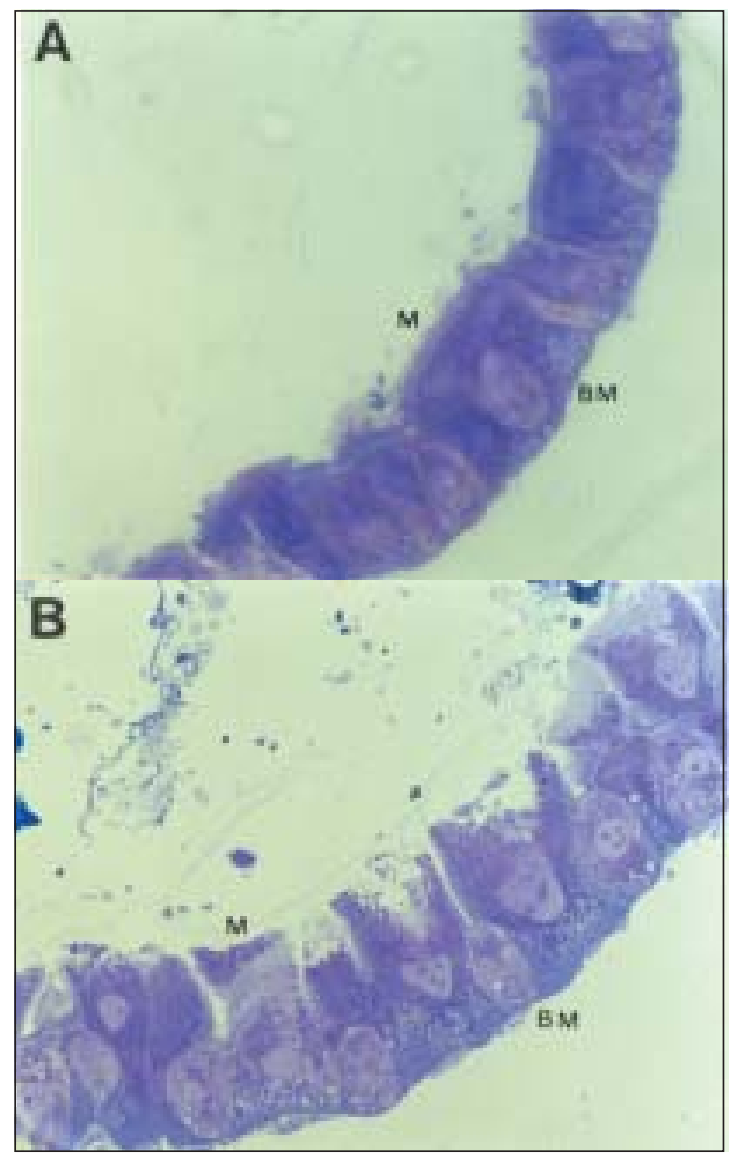

Figure 2. Basal membrane (BM) and microvilli (M) of midgut sections in cotton boll weevil larvae without treatment (A) and six days after artificial diet containing $53 \mu \mathrm{g} / \mathrm{mL}$ of cholesterol oxidase (B). Magnification: $\mathrm{x} 400$ and $\mathrm{x} 415$, respectively; stain: toluidine blue. 
basal membrane and highly vacuolated regions in the epithelial cells (Figures 2B, 3D, 3E and 3F), characteristics that point to cell degeneration. FainMaurel et al. (1973) and Martoja \& Ballan-
DuFrançais (1984) mentioned that cell degeneration is characterized by an increase in the number and volume of autophageous vacuoles and generally appears in cells fated to die. Purcell et al. (1993), who

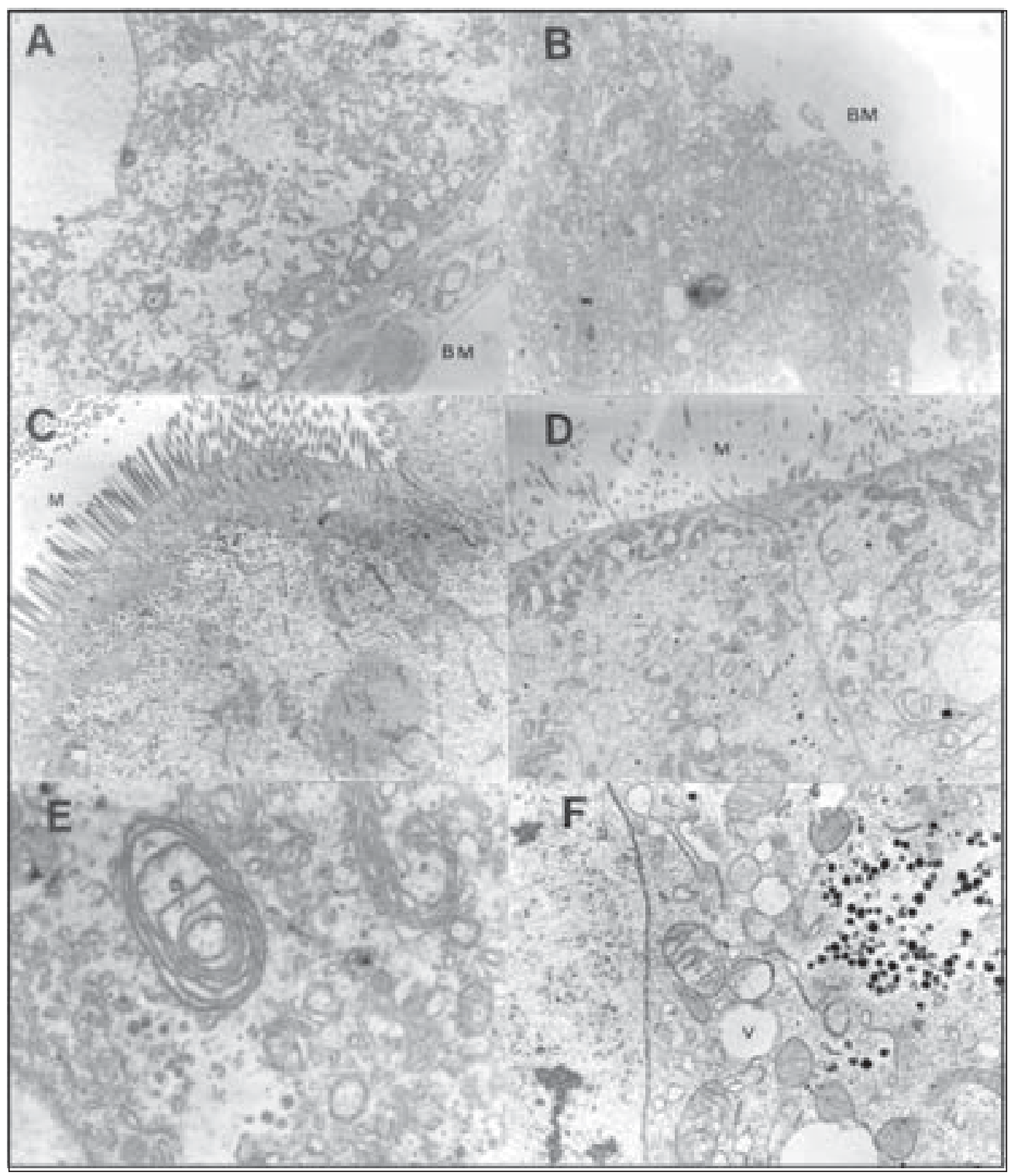

Figure 3. Electron micrographs of cotton boll weevil midguts showing the basal membrane (BM), the microvilli (M) and the vacuoles (V) of controls (A, C and E; magnification: $\mathrm{x} 9.500, \mathrm{x} 6.900$ and $\mathrm{x}$ 17.500 , respectively) and of individuals reared on artificial diet containing $53 \mu \mathrm{g} / \mathrm{mL}$ of cholesterol oxidase (B, D and F; magnification x 9.200, x 7.500 and x 18.500, respectively). 
reported disruption of the boll weevil midgut cells, made similar observations at $10 \mu \mathrm{g} / \mathrm{mL}$ and complete lysis of the cells between 30 to $100 \mu \mathrm{g} / \mathrm{mL}$ of Coase.

According to Gottlieb (1977), the effect of Coase on erythrocyte membranes is most likely due to the substitution of the membrane cholesterol through the reaction product, $\Delta^{4}$-cholestenone, and the reaction of membrane components with $\mathrm{H}_{2} \mathrm{O}_{2}$ produced by the enzyme reaction.

Cholesterol is an important component in boll weevil metabolism. According to Earle et al. (1967), larvae require a minimum of $20 \mathrm{mg}$ of cholesterol per $100 \mathrm{~g}$ of diet for normal development. In order to guarantee this supply, boll weevil feed and lay eggs predominantly on cotton squares and bolls and the insect removes the cholesterol precursor $\beta$-sitosterol from floral structures (about $87 \%$ in buds and $78 \%$ in cotton anthers) converting it to cholesterol.

The development of boll weevil is highly dependent on the availability of cholesterol, and cholesterol oxidase has shown, here and in previous works, antagonistic to the normal physiology of the insect. Therefore, this enzyme might well represent an alternative to other proteins, such as Bacillus thuringiensis toxins or proteinase inhibitors, which have been contemplated or used for the construction of transgenic, insect resistant cotton plants.

\section{Conclusions}

1. Larval viability of boll weevil is affected by cholesterol oxidase at all enzyme concentrations, and the six-day $\mathrm{LD}_{50}$ is $53 \mu \mathrm{g} / \mathrm{mL}\left(\mathrm{CI}_{95 \%}\right.$ : 43-59).

2 . Emergence of larvae is also affected by cholesterol oxidase solution at different concentrations.

3. Larvae fed on artificial diet containing cholesterol oxidase show highly vacuolated regions in the epithelial cells as well as partial degradation of the basal membrane and microvilli.

\section{Acknowledgement}

To Dr. David Bertioli from Embrapa-Centro Nacional de Pesquisa de Recursos Genéticos e Biotecnologia, for critical reading of the manuscript.

\section{References}

ALMEIDA, R. P. Economic threshold for the cotton boll weevil (Anthonomus grandis Boheman) control. Proceedings of Experimental and Applied Entomology, Amsterdam, v. 11, p. 97-102, 2000.

BELTRÃO, N. E. M. O agronegócio do algodão no Brasil. Brasília: Embrapa-SPI, 1999. v. 1.

EARLE, N. W.; WALKER, A. B.; BURKS, M. L.; SLATTEN, B. H. Sparing of cholesterol by cholestanol in the diet of the boll weevil, Anthonomus grandis (Coleoptera: Curculionidae). Annals of the Entomological Society of America, Lanham, v. 60, n. 3, p. 599-603, 1967.

FAIN-MAUREL, M. A.; CASSIER, P.; ALIBERT, J. Étude infrastructurale et cytochimique de l'intestin moyen de Petrobius maritimus Leach en rapport avec ses fonctions excrétrices et digestives. Tissue \& Cell, Edinburgh, v. 5, p. 603-631, 1973.

GABRIEL, D.; CALCAGNOLO, G.; TANCINI, R. S.; DIAS NETTO, N. Estudos de biologia do Anthonomus grandis Boheman, 1843 (Coleoptera: Curculionidae) em condições de laboratório. Biológico, São Paulo, v. 52, n. 10, p. 83-90, 1986.

GOTTLIEB, M. H. The reactivity of human erythrocyte membrane cholesterol with a cholesterol oxidase. Biochimica et Biophysica Acta, Amsterdam, v. 466, p. 422-428, 1977.

GREENPLATE, J. T.; DUCK, N. B.; PERSHING, J. C.; PURCELL, J. P. Cholesterol oxidase: an oostatic and larvicidal agent active against the cotton boll weevil, Anthonomus grandis. Entomologia Experimentalis et Applicata, Dordrecht, v. 74, p. 253-258, 1995.

LANGE, Y. Tracking cell cholesterol with cholesterol oxidase. Journal of Lipid Research, Bethesda, v. 33, p. 315321, 1992.

MARTOJA, R.; BALLAN-DUFRANÇAIS, C. The ultrastructure of the digestive and excretory organs. In: KING, R. C.; AKAI, H. (Ed.). Insect ultrastructure. New York: Plenum, 1984. p. 199-268.

MONNERAT, R. G.; DIAS, S. R.; SÁ, M. F. Dieta artificial para criação do bicudo do algodoeiro em laboratório. Revista Brasileira de Entomologia, São Paulo, v. 5, p. 36-40, 1999. 
PURCELL, J. P.; GREENPLATE, J. T.; JENNINGS, PURCELL, J. P.; ISAAC, B. G.; TRAN, M.; SAMMONS, M. G.; RYERSE, J. S.; PERSHING, J. C.; SIMS, S. R.; R. D.; GILLESPIE, J. E.; GREENPLATE, J. T.; SOLSTEN, PRINSEN, M. J.; CORBIN, D. R.; TRAN, M.; R. T.; PRINSEN, M. J.; PERSHING, J. C.; STONARD, R. J. SAMMONS, R. D.; STONARD, R. J. Cholesterol oxi- Two enzyme classes active in green peach aphid bioassays. Jourdase: a potent insecticidal protein active against boll weevil larvae. Biochemical and Biophysical Research Communications, Orlando, v. 196, p. 1406-1413, 1993. nal of Economic Entomology, Lanham, v. 87, p. 15-19, 1994. SAS INSTITUTE (Cary, Estados Unidos). SAS/STAT user's guide: version 8. Cary, 1999. 